\section{Hanyang Medical Reviews}

Hanyang Med Rev 2013;33:27-32

http://dx.doi.org/10.7599/hmr.2013.33.1.27

pISSN 1738-429X eISSN 2234-4446

\section{Interleukin-17의 발현이 염증성장질환의 발생과 진행에 끼치는 영향}

이초롱 · 박성규

광주과학기술원 생명과학부

\title{
Interleukin-17 in the Inflammatory Bowel Disease
}

\author{
Cho-Rong Lee, Sung-Gyoo Park \\ School of Life Sciences, Gwangju Institute of Science and Technology, Gwangju, Korea
}

Inflammatory bowel diseases(IBD), including Crohn's disease and ulcerative colitis, are chronic inflammatory states of the intestinal tract. While the exact mechanisms inducing chronic inflammation are still unclear, it is hypothesized that the inflammation is caused in part by an inappropriate immune response to the intestinal microflora. Although inflammatory diseases are not directly linked to patient survival, symptoms of these diseases significantly decrease quality of life. The incidence rate is higher in western people than eastern people, but the incidence rate of IBD in eastern people, including Korean, is increasing. Recently, it has been reported that IL-17 is an important factor that appears to be involved in IBD induction and progression. This report reviews many recent papers reporting the relationship between IBD and IL-17, which may provide an understanding leading to new means of prevention and treatment for IBD.

Key Words: Colitis; Interleukin-17;Th17 Cells; Receptors, Antigen, T-Cell, gamma-delta
Correspondence to: Sung-Gyoo Park 우500-712, 광주광역시 북구 첨단과기로 123 , 광주과학기술원 생명과학부 305 호 305-ho, School of Life Sciences, 123 Cheomdangwagi-ro, Buk-gu, Gwangju 500-712, Korea

Tel: +82-62-715-2511

Fax: +82-62-715-3551

E-mail: sgpark@gist.ac.kr

Received 15 November 2012

Revised 4 January 2013

Accepted 10 January 2013

This is an Open Access article distributed under the terms of the Creative Commons Attribution Non-Commercial License (http://creativecommons.org/licenses/by-nc/3.0) which permits unrestricted non-commercial use, distribution, and reproduction in any medium, provided the original work is properly cited.

\section{서 론}

염증성장질환은 장에 염증이 발생하는 질환을 말한다. 염증성 장질환은 그 증상 및 발생 경과에 따라 크게 크론병(Crohn's disease) 및 궤양성대장염(ulcerative colitis)으로 구분된다. 이와 같은 장염의 발생 원인은 현재까지 명확하게 밝혀져 있지 않으나, 장내의 미생물에 대한 과도한 면역반응이 매개되는 것으로 생각되고 있다. 염증성장질환은 환자의 생명과는 직접적인 연관성이 없지만, 환자 의 삶의 질을 급격히 감소시키는 질환이다. 하지만 아직 이 염증성 장질환을 완치시킬 수 있는 약물치료법이 개발되지 못하고 있다. 원 래 서구에서 그 유병률이 높았지만, 현재는 우리나라에서도 꾸준 히 그 유병률이 높아지고 있는 것으로 알려져 있어, 이제는 염증성 장질환이 우리나라에서도 문제로 대두되고 있다. 이 염증성장질환 에서 최근 IL-17의 발현이 증가하는 것으로 알려져 있으며, 현재 이 렇게 증가된 IL-17의 역할에 대한 연구가 많이 진행되고 있다.
본 론

\section{1. 크론병(Crohn's disease)}

크론병은 입에서 항문까지 소화관의 어느 부위에서나 염증이 발 생할 수 있는 장질환이다[1,2].

일반적으로 작은창자의 말단부나 큰창자의 말단부에 발생하며, 증상으로는 설사, 복통, 열, 그리고 때때로 직장출혈을 동반하며, 이 에 따르는 체중저하가 일어나기도 한다. 유전적 요인이 장질환에 작 용하고 있으며, 이 질환의 치료 방법으로는 약물치료 방법과 수술 적 치료 방법이 있다. 약물치료 방법에는 aminosalicylate, 스테로이 드, 면역조절제, 그리고 항생제 등이 쓰이고 있으며, 수술적 치료는 장기간의 약물치료, 장변형 또는 장출혈 등 증상이 심할 경우 사용 되는 치료법이다. 이와 같은 치료법의 존재에도 불구하고, 크론병 의 완치는 불가능한 것으로 알려져 있다. 


\section{2. 궤양성대장염(ulcerative colitis)}

궤양성대장염은 주로 대장에 국한하여 염증이 생기는 장질환으 로, 증상으로는 발열, 하부복통, 설사 등이 보이며, 심할 경우 장에 구멍이 뜷리는 등 중증이 동반되기도 한다[1,2]. 대부분의 염증성 장질환의 경우와 같이 수액요법, 금식, 약물투여 요법 등이 치료법 으로 알려져 있다. 궤양성대장염 중 약 $20 \%$ 정도가 수술적 치료가 필요한 것으로 알려져 있으며, 이와 함께, 항염증제제, 스테로이드 등의 약물치료 방법이 쓰이고 있다. 궤양성 대장염도 크론병과 마 찬가지로 완치는 불가능한 것으로 알려져 있다.

\section{3. 염증성장질환의 발생}

염증성장질환은 전통적으로 아시아 지역보다는 서구에서 그 발 병률이 높은 것으로 알려져 있으며, 서구의 경우 염증성장질환을 가지고 있는 사람의 수가 전체 인구의 $0.5 \%$ (캐나다 기준[3])에 이 를 만큼 심각한 양상을 보인다. 실제, 염증성장질환을 가지고 있는 경제활동 인구 중 증상의 악화로 경제 활동을 할 수 없는 일이 많 아, 이 질병으로 인하여 간접적으로도 경제활동에 영향을 끼치는 것으로 알려져 있다.

우리나라의 경우, 1986-1990년대까지만 해도 크론병과 궤양성대 장염의 발생률이 인구 10 만 명당 각각 $0.05 \%$ 와 $0.34 \%$ 로 아주 희귀 질환이었다. 하지만 2005-2006년, 크론병과 궤양성대장염의 발생 률이 인구 10 만 명당 각각 $2.7 \%$ 와 $3.3 \%$, 그리고 2007-2008년, 그 발 생률이 각각 5.1\%와 5.4\%로 그 발생률이 꾸준히 증가되어 있다[4]. 현재 우리나라의 염증성장질환의 발생률은 서구의 염증성장질환 의 발생률에 비하여, 이제는 현저히 낮은 편은 아닌 것으로 알려져 있다.

\section{4. 염증성장질환의 치료}

염증성장질환에 대한 치료는 위에서 말한 바와 같이 약물치료 와 수술에 의한 치료로 나뉘어진다. 하지만 어느 치료 방법도 현재 기술로는 완치를 위한 치료를 하지 못하며, 지속적인 약물 복용 또 는 지속적인 관리가 필요하다. 즉, 경제 활동 인구의 경제활동을 방 해할 뿐만 아니라, 염증성장질환을 가지고 있는 환자의 관리를 위 한 약물치료 비용 및 수술적 치료 비용 등의 사회적 비용이 우리나 라에서 발병률의 증가와 함께 지속적으로 증가하고 있다 $[5,6]$.

약물치료의 경우, 염증성장질환 치료를 위하여 aminosalicylate, 스테로이드, 면역조절제, 그리고 항생제 등 기존의 약물이 쓰이고 있고, 완치가 되지 않아 장기간 투여 시 부작용이 심해지는 경향을 가지고 있다. 따라서 이 질환을 가지고 있는 사람들은 지속적으로 약물을 복용하려고 하지만, 부작용의 위험성으로 안정적인 약물 을 공급받지 못하고 있다. 염증성장질환의 연구를 통한 이상적인 표적(단백질, 세포, 또는 상호작용 등)을 찾아 부작용이 없는 치료 약물 또는 치료 기술을 개발한다면, 향후 약물 개발 및 약물 생산
과 같은 산업적인 요인이 발생할 수 있을 것으로 기대된다[5,6].

\section{5. 염증성장질환에서 IL-17의 역할}

1) IL-170이란?

염증성 장질환 inflammatory bowel disease (IBD)에 주요 형태 인 크론병과 궤양성대장염은 고유미생물상에 대한 과도하거나 결 핍된 면역 반응에 의해 야기된다고 알려져 있다[7]. 최근의 논문들 을 통해, 크론병과 궤양성대장염에 관련된 염증반응은 $\mathrm{Th}$ 세포의 구성원으로서 최근에 밝혀진 Th17세포에 의해 만들어진 시토카인 들의 증가와 관련 있다는 사실이 밝혀졌으며, 이러한 Th17 시토카 인들은 장에서 조직을 보호하거나 염증성 효과를 가질 수 있다고 알려져 있다[7,8].

\section{(1) IL-17을 발현하는 세포 및 IL-17을 발현하는 세포의 분화}

Th17세포는 우선적으로 IL-17A, IL-17F, IL-21, IL-22를 생산할 수 있는 세포로 알려져 있다. 이때, IL-17A는 일반적으로 IL-17이라 고 불리며 Th17세포에 의해 생산되는 중요 시토카인 중의 하나이 다[9,10].

IL-17A와 IL-17F는 TGF-beta, IL-6, IL-21을 포함하는 여러 시토 카인에 의해 미감작(naïve) $\mathrm{CD}_{4}^{+} \mathrm{T}$ 세포가 $\mathrm{Th} 17$ 세포로 분화하게 되 면서 주로 생성되는데, Th17세포뿐만 아니라 세포 독성 $\mathrm{CD}^{+} \mathrm{T}$ 세 포(Tc17)와 $\gamma \delta$ T세포, NKT (NKT-17)세포와 같은 다양한 T세포에 서도 생산할 수 있으며, 최근에 밝혀진 보고에 의하면 호중구, 단핵 백혈구, 자연살해세포, Lymphoid tissue inducer cell (LTi)세포와 같은 선천성 림프성 세포와 비면역 세포인 장에 존재하는 파네트 (paneth)세포, IL-17F는 결장의 상피세포에서도 발현될 수 있다 $[9,11,12]$.

IL-17E는 선천성, 후천성 면역반응에서 중요한 역할을 한다고 알 려져 있는데, 항원이나 병원균의 자극에 의해 $\mathrm{T}$ 세포, 선천성면역 세 포, 비면역 세포 등의 다양한 종류의 세포에서 IL-17E를 생산한다 $[9,13]$.

IL-17B의 경우 여러 신체기관에서 볼 수 있지만, 주로 연골세포 와 뉴런에서 높게 발현된다[14]. IL-17C의 경우, 염증부위의 $\mathrm{CD} 4^{+}$ $\mathrm{T}$ 세포, 수지상 세포, 대식세포 등에서 발현되는데, 대부분의 정상 조직에서는 발현되지 않는다[9,15-17]. IL-17D는 IL-17B와 같이 여 러 조직에서 발현될 수 있지만 면역세포에서는 휴지기 $\mathrm{CD} 4^{+} \mathrm{T}$ 세포 와 휴지기 B세포에서만 발현된다[9,18].

\section{(2) ㄴ-17의 구성}

마우스에서의 IL-17A는 147 개의 아미노산 잔기를 포함하는 21 $\mathrm{kDa}$ 의 당단백질로서 인간의 IL-17A과 $63 \%$ 의 아미노산을 공유하 며, 이들은 이황화물로 연결된 동형이합체의 형태로 분비된다. 최 근에 밝혀진 IL-17B, IL-17C, IL-17D, IL-17E, IL-17F 이들 5개의 시 
토카인이 IL-17A와 구조적으로 연관되어있으며 IL-17 family를 구 성하고 있다 $[9,19,20]$. 그리고 이들 각각의 구성원들은 $16 \%$ 에서 $50 \%$ 의 아미노산 동일성을 보인다. 이들 family 구성원들 중에서, IL-17A와 IL-17F는 가장 높은 아미노산 서열의 동일성을 보이는 반 면, IL-17E는 가장 낮은 $16 \%$ 의 동일성을 보인다[9].

가장 높은 동일성을 지닌 IL-17A와 IL-17F는 서로 같은 수용체 에 결합하고 분비될 때 이황화물로 연결된 동형이합체나 이질이합 체의 형태로 분비되는데, 이는 두 시토카인이 비슷한 생물학적 활 성을 지닐 수 있다는 가능성을 의미한다[9,11,21].

\section{(3) IL-17 수용체의 구성}

이와 같은 IL-17 family의 IL-17의 수용체 family는 IL-17RA에서 IL-17RE의 5 개의 구성원을 포함하며, extracellular fibronectin IIIlike 영역(domain)과 Toll-IL-1R family (SEFIR) 도메인과 같은 보 존된 구조적 특징을 지닌다[13]. IL-17 family 시토카인의 기능적인 수용체는 동형이합체나 이질이합체의 형태로 구성되는데, IL$17 R A$ 와 IL-17RC의 이질이합체는 IL-17A와 IL-17F의 동형이합체 와 이형이합체의 수용체이고, IL-17RA와 IL-17RB의 이질이합체 는 IL-17E의 수용체로 알려져 있다. 또한 IL-17B와 IL-17E는 IL$17 \mathrm{RB}$ 에 결합하고, $\mathrm{IL}-17 \mathrm{C}$ 는 IL-17RE에 결합하여 NF- $\mathrm{KB}$ 를 활성화 시킨다고 최근에 보고되었으나 IL-17D의 수용체와 IL-17RD의 리 간드에 대해서는 아직 밝혀진 바가 없다[9].

\section{(4) IL-17의 기능}

IL-17A와 IL-17F는 염증성 시토카인인 TNF, IL-1, IL-6, G-CSF, GM-CSF와 케모카인인 CXCL1, CXCL5, IL-8, CCL2, CCL7와 항 미생물 펩타이드인 defensins, S100 단백질 그리고 MMP1, MMP3, MMP13과 같은 matrix metalloproteinase (MMP)를 암호화하는 유전자를 발현하여 염증반응 발달과 외부 감염에 대한 숙주방어 에 관여한다. 분비된 IL-17A와 IL-17F는 T세포, B세포, 대식세포와 같은 면역세포를 활성화하여 $\mathrm{T}$ 세포 프라이밍(priming)이나 항체 생성, 염증성 시토카인 생산을 촉진시키고, 비면역 세포에서 시토 카인과 케모카인, MMP, VEGF, RANKL, 항미생물 펩타이드와 같 은 여러 염증성 매개자를 유도하여 염증부위에 호중구를 불러오 거나 국소의 조직파괴를 촉진시킬 수 있고, 종양에서는 신혈관 형 성을 유도시키고, 파골세포 형성 증가와 병원균으로부터 보호 작 용 등의 역할을 할 수 있다. 특히 IL-17A는 자가면역질환이나 알레 르기 반응, 종양발달, 세균이나 곰팡이 감염에 대한 숙주방어 등에 주로 관여하는 반면, $\mathrm{IL}-17 \mathrm{~F}$ 는 주로 점막과 상피조직에서 중요한 역할을 한다[9,11,12].

IL-17 family구성원들이 주로 염증성 반응에 관여하는데 비해, IL-17E (IL-25)는 IL-4, IL-5, IL-13과 같은 Th2 세포의 시토카인을 유도하여 Th2 세포 및 natural killer T (NKT)세포, Th9세포 등의
면역반응을 증가시키거나 immunoglobulin E (IgE)의 생산을 유도 할 수 있고, 호산구를 과다분비시켜 선충류에 대한 방어와 알레르 기 장애에 기여한다고 알려져 있다[9,13].

IL-17B, IL-17C, IL-17D는 IL-17A와 IL-17F와 같이 염증성 매개 자를 유도하여 유사한 역할을 한다고 하지만[9], 면역체계에서 정 확하게 어떤 일을 하는지에 대해서는 여전히 알려져 있지 않다. IL$17 \mathrm{~B}$ 의 신호전달 기전에 대해서는 알려진 바가 없다. IL-17C의 경우 IL-17RE 수용체에 결합하여 NF- $\mathrm{kB}$ 를 활성화시킬 수 있다. IL-17D 의 경우에 결합하는 수용체에 대한 정보가 없어, 많은 연구가 진행 되어 있지 않다. 최근에 이루어진 연구 결과에 따르면, 기능적으로 잘 알려져 있지 않았던 IL-17C가 dextran sulfate sodium (DSS)으 로 유도한 급성 장염 모델을 조절하는데 중요하다는 사실이 밝혀 졌는데, 이는 IL-17C가 결핍된 마우스에서 Th17세포와 $\gamma \delta \mathrm{T}$ 세포에 의해 증가된 IL-17에 의해 장염이 악화되는 결과를 통해 확인하였 다. 그 뿐만 아니라 IL-17C가 결장 상피세포에서 밀착연접의 분자 인 occludin의 발현을 직접적으로 조절하여 점막 장벽의 안정성 유 지에도 중요한 역할을 한다는 사실을 확인하였다[22].

\section{2) 장에서 감염성 세균에 대한 역할}

IL-17의 숙주 방어적인 역할은 병원균 제거와 조직 보호의 기능 으로 나누어진다 $[8,23,24]$. 장관에서 미생물에 대한 숙주 방어에 있어, IL-17A, IL-17F와 IL-22가 Citrobacter rodentium 의 경구 감 염을 조절하는데 중요하다는 사실을 이들 시토카인이 결핍된 마우

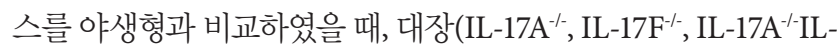
$\left.17 \mathrm{~F}^{-1}\right)$ [25], 장간막의 림프절, 비장, 간(IL-22/) [26] 등에서 증가된 Citrobacter rodentium 의 양을 통해 확인하였다[8]. 증가된 세균의

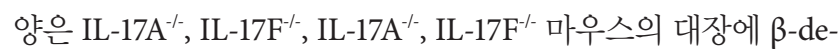
fensins $1,3,4$ 의 감소와 연관되어 있다는 것이 알려졌다. 즉, IL-17은 감염성 세균의 방어에 있어 중요한 역할을 한다는 것이 일반적인 견 해이다[8,25].

\section{3) 장염 발생 모델에서의 IL-17A의 역할}

장 손상에 의한 장염 발생에서 IL-17 시토카인들의 조직 보호 효 과가 있다는 보고가 있다. 이 중 좋은 예는 IL-17A에 대한 항체를 처 리하거나 유전자를 제거하여 중화시켰을 때, DSS 장염 모델에서 장염이 악화되는 것이다 $[8,27,28]$. 마우스에게 마시는 물을 이용하 여 DSS를 며칠간 처리하는 것은 상피층에 구조적인 붕괴와손상에 의한 급성 염증반응을 일으키며, 빠르고 일시적인 체중감소를 일 으킨 후 뒤이어 정상적으로 회복하게 한다[8]. IL-17A는 이와 같은 모델에서 장 상피세포에서 claudins의 발현을 유도하고, 점액소의 생산을 자극하여 밀착 연접 형성을 강화시켜, 점막 장벽 기능이 증 가함으로써 숙주 방어적인 효과를 발휘한다고 하였다 $[8,29,30]$. 유 사하게도 야생형의 마우스와 비교할 때, IL-22가 결핍된 마우스에 
서 DSS 처리 후에 체중감소 촉진과 높은 사망률을 보였으며, 이로 써 IL-22의 조직 보호적인 역할을 제시하였다[8,31]. 실제로 IL-22 는 장 상피세포 증식을 증가시키고[32], 배상세포 복원과 점액 생산 을 늘려 장벽의 온전함을 촉진하였다 $[8,33]$.

장염 발병에서 비T세포에서 유래된 Th17 유형의 시토카인에 대 한 T세포의 역할을 분명히 하기 위해, 몇몇의 그룹에서 $\mathrm{CD} 45 \mathrm{RB} \mathrm{B}^{\mathrm{high}}$ $\mathrm{CD}^{+} \mathrm{T}$ 세포 전달 모델을 이용하였고, 여기에서 공여되는 $\mathrm{CD} 4^{+}$세 포 및/또는 세포를 받는 $\mathrm{Rag}^{-/}$마우스를 각각의 시토카인을 결핍시 켜 만들 수 있었다. 현재까지 대다수의 연구들에서 시토카인이 결 핍된 $\mathrm{CD} 45 \mathrm{RB}^{\mathrm{high}} \mathrm{CD} 4^{+} \mathrm{T}$ 세포와 이러한 세포를 정상 시토카인이 충분한 $\mathrm{Rag}^{-1 /}$ 마우스에 전달하여 이용하였다. 이로써 $\mathrm{IL}-17 \mathrm{~A}^{-1}$ $\mathrm{CD}_{4} 5 \mathrm{RB}^{\text {high }} \mathrm{CD}^{+} \mathrm{T}$ 세포는 세 개의 독립적인 결과를 통해 야생형 의 $\mathrm{CD}_{4} 5 \mathrm{RB}^{\mathrm{high}} \mathrm{CD}^{+} \mathrm{T}$ 세포에 의해 유도되는 심각한 장염상태와 동일한 결과를 보였다 $[8,34,35]$. 여기서 증명되는 사실은 $\mathrm{T}$ 세포에 서 유도된 IL-17A는 장염유도에는 중요하지 않다는 것이다[8]. 유사 한 네 번째 연구에서 $\mathrm{IL}-17 \mathrm{~A}^{--} \mathrm{CD} 45 \mathrm{RB}^{\text {high }} \mathrm{CD} 4^{+}$T세포에 대한 야생 형의 $\mathrm{Rag}^{-1}$ 마우스의 장에서의 장염 발병에 미세한 차이를 보였다. 하지만 IL-17A가 결핍된 T세포를 가진 마우스에서는 체중 감소가 촉진되는 것을 보고하였고[36], 이는 아마 T세포의 IL-17A와 연관 된 방어 효과의 결핍 때문일 것이다[8].

각각의 Th17 유형의 시토카인이 방어적이거나 병원성 역할이 쉽 게 나타나는 DSS와 trinitrobenzenesulphonic acid (TNBS)에 의한 급성 장염모델과는 대조적으로, $\mathrm{T}$ 세포 전달 모델 같은 만성 장염모 델은 더욱 복잡하거나 다수의 시토카인의 저해가 질병 발병에 영 향을 주기 위해 필요하다[8]. 위에서 언급된 T세포에서 유도된 IL$17 \mathrm{~A}$ 는 $\mathrm{T}$ 세포 전달 장염모델에서 불필요하다는 연구결과를 따라 [34-37], 야생형의 $\mathrm{CD} 45 \mathrm{RB}^{\text {high }} \mathrm{CD} 4^{+}$T세포가 주어진 $\mathrm{Rag}^{-/}$마우스 에 anti-IL-17A 항체를 처리하여 시토카인을 제거할 때 염증반응에 아무런 효과가 없는 것을 확인하였다 [8,37].

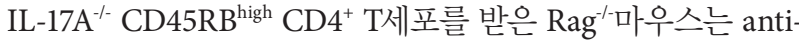
IL-6R 항체를 주었을 때 장에서의 염증 감소를 보였고[35], anti-IL$17 \mathrm{~A}$ 와 anti-IL-6 항체를 결합하여 처리할 때, 야생형의 CD45RB ${ }^{\text {high }}$ $\mathrm{CD}_{4}^{+}$T세포와 IL-23을 받은 $\mathrm{Rag}^{-/}$마우스에서 장의 염증 심화가 상당히 완화되는 것을 보았다[8,38]. 이러한 사실들을 종합하여 볼 때, 만성 장염에서 각각의 Th17과 관련된 시토카인 저해는 유익한 효과를 보기에 충분하지는 않지만, 대신에 여러 경로 타겟팅과 $\mathrm{Th} 17$ 반응과 Th17세포 발달과 관련된 중개자에는 필수적이다. 결 과적으로 Th17 림프구의 기능과 분화에 대해 더 알아가는 것이 장 에서 염증 치료 발전에 중요하다고 할 수 있다[8].

\section{4) 장염 발생 모델에서의 IL-17F의 역할}

IL-17F가 결핍된 마우스에서 DSS가 주어졌을 때 야생형 마우스 보다 가벼운 증세를 보였고, 이는 IL-17F가 이와 같은 모델에서 염
증상태를 악화시킨다는 것이다. 실제로 DSS를 먹인 IL-17F-/ 마우 스는 동일하게 처리한 야생형의 대조군과 비교하였을 때, 대장에서

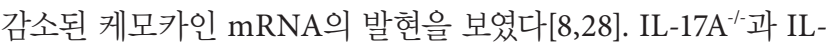
$17 \mathrm{~F}^{-/}$마우스가 DSS 처리 후에 서로 다른 질병 결과를 보이는 이유 에 대해서는 아직 불분명하다. 두 시토카인은 골수계 세포와 내피 세포에서 같은 수용체에 결합하고, IL-1 $1 \beta$, IL-6, tumor necrosis factor- $\alpha$ (TNF- $\alpha$ ) 그리고 호중구 모집에 관련된 케모카인들의 발현을 유도한다 $[8,9,19]$.

$\mathrm{IL}-17 \mathrm{~A}^{-1} \mathrm{CD} 45 \mathrm{RB}^{\mathrm{high}}$ 세포를 이용한 결과와 비슷하게, $\mathrm{IL}^{-17 \mathrm{~F}^{-1}}$ 또는 IL-22 ${ }^{-1}$ 에서 분리한 $\mathrm{CD}_{4} 5 \mathrm{RB}^{\text {high }} \mathrm{CD} 4^{+}$T세포가 야생형의 T세 포와 동일하게 장염을 유도함으로써 T세포에서 유도된 IL-17F나 $\mathrm{IL}-22$ 는 T세포 전달 모델에서의 장염 발병에 필요하지 않는 것으로 보였다 $[8,37]$. 다른 독립된 연구에서 IL-22는 T세포 전달 장염모델 에서 방어적인 역할을 한다고 보이기도 하였다. 그러므로 다양한 조합의 $\mathrm{CD} 45 \mathrm{RB}^{\mathrm{high}} \mathrm{T}$ 세포와 $\mathrm{Rag}^{-/}$마우스를 IL-22를 생산하는 능 력이 있을 때와 없을 때로 나누어 실험하였을 때, 제공되는 $\mathrm{CD}_{45 \mathrm{RB}} \mathrm{high}^{\mathrm{T}} \mathrm{T}$ 세포와 받는 $\mathrm{Rag}^{-1}$ 마우스의 IL-22가 부족할 때 가장 심각한 장염상태가 관찰되었다. 이러한 결과들은 $\mathrm{T}$ 세포와 비 $\mathrm{T}$ 세포 양쪽에서의 IL- 22제공이 T세포 전달 장염 모델에서 조직을 보호 하는 역할을 하고 있음을 제시한다[8,31].

야생형의 $\mathrm{CD}_{4} 5 \mathrm{RB}^{\text {high }} \mathrm{CD}^{+}$T세포가 주어진 $\mathrm{Rag}^{-/}$마우스에 anti-IL-17A 항체를 처리하여 시토카인을 제거할 때 염증반응에 아무 런 효과 없는 결과와는 대조적으로 같은 연구에서 $\mathrm{IL}^{-17 \mathrm{~F}^{-1}}$ $\mathrm{CD}_{4} 5 \mathrm{RB}^{\text {high }} \mathrm{CD}^{+} \mathrm{T}$ 세포를 받은 $\mathrm{Rag}^{-/}$마우스에 anti-IL-17A 항체 를 처리할 때 장염이 완화되어 이러한 모델에서 IL- $17 \mathrm{~A}$ 와 IL-17F의 과도한 병원성 효과를 제시하였다[8,37].

\section{5) 장염 발생 모델에서의 IL-21의 역할}

DSS와 TNBS 장염에서 병원성 역할을 하는 또 하나의 Th17 유 형의 시토카인이 IL-21이다. 이 때문에 IL-21/ 마우스에 이러한 화 합물이 투여될 때, 야생형의 대조군과 비교하여 염증발달에 감소 를 보였고, DSS가 주어진 야생형의 마우스에 IL-21R-Fc 융합 단백 질을 처리하면 장염이 약화되었다[8,39]. IL-21은 매우 다양한 효과 를 가지는데, 이는 장에서의 염증반응 유도에 기여한다. 예를 들어 IL-21은 장 섬유모세포로부터 조직을 분해하는 MMPs의 생산 유 도와[40] 장 상피세포에서 T세포 화학유인물질인 macrophage inflammatory protein-3a (MIP-3a)/CCL20의 합성을 자극하고[41], $\mathrm{CD} 25-\mathrm{CD} 4^{+} \mathrm{T}$ 세포에 조절 면역세포와 연관된 억제반응에 저항성 을 가지게 하며[42,43], 경우에 따라서는 T세포와 자연살생 세포로 부터 IFN- $\gamma$ 의 생산을 증가시킨다 $[8,44,45]$. 또한 T세포에서 유도된 IL-21은 Th17세포를 유도하기 위해 자가분비(autocrine) 방식으로 역할을 한다고 알려져 있다[8,46-48]. 종합하여 보면, DSS나 TNBS 와 같은 화학물질로 상피 장벽이 손상된 급성 장염 모델에 관한 연 
구들에서 서로 다른 Th17 유형의 시토카인들이 구별되는 역할을 한다고 알려졌으며, 몇몇은 조직 보호적이고(IL-17A, IL-22), 다른 몇몇은 병원성 역할을(IL-17F, IL-21) 가진다[8].

\section{6) 특정 유전자 결핍에서 일어나는 자연발생 장염에서의 IL-17의 역할}

최근의 연구에서 TCRaß T세포 특이적으로 마우스에서 $P d k 1$ 유전자를 제거하면, TCR $\gamma \delta \mathrm{T}$ 세포에 의해 자연발생 장염이 생김이 알려졌다[49]. 이 모델에서는 TCR $\gamma \delta$ T세포군 중에서 IL-17A을 발 현하는 $\mathrm{TCR} \gamma \delta \mathrm{T}$ 세포가 장에서 급격하게 증가하였다. 이 결과는 장염의 유도에서 TCR $\gamma \delta \mathrm{T}$ 세포에서 발현된 IL-17A가 장염의 발생 과 연관이 되어 있음을 보여준다. 실제, 조절 $\mathrm{T}$ 세포(regulatory $\mathrm{T}$ cell)를 이식하면, 이 마우스에서도 장염이 발생하지 않으며, 또한 $\mathrm{TCR} \gamma \delta \mathrm{T}$ 세포 중 IL-17A를 발현하는 세포가 급격히 줄어들었다. 이 연구와 함께 TCR $\beta^{-/}$마우스에 $\mathrm{CD}$ T세포를 이식하면 장염이 발 생하는데, 이 마우스에도 마찬가지로 IL-17A를 발현하는 TCR $\gamma \delta \mathrm{T}$ 세포의 수가 증가하였으며, 이 IL-17A가 장염을 악화시킨다고 보고 되었다[50]. 이 연구에서는 미감작 $\mathrm{CD} 4^{+} \mathrm{T}$ 세포를 $\mathrm{TCR} \beta-/-\mathrm{TCR} \delta^{-/}$ 마우스에 이식하면 장염 증상이 완화되고, 미감작 $\mathrm{CD} 4^{+} \mathrm{T}$ 세포를 $\mathrm{TCR} \gamma \delta \mathrm{T}$ 세포와 함께 $\mathrm{TCR} \delta^{-1}$ 마우스에 같이 이식하면 장염의 증 상이 다시 악화되었다. 이런 장염의 유도는 CCR6- TCR $\gamma \delta \mathrm{T}$ 세포에 의한 것이 아니라, CCR6 ${ }^{+} \mathrm{TCR} \gamma \delta \mathrm{T}$ cell (IL-17A을 생산하는 TCR $\gamma$ $\delta \mathrm{T}$ 세포)에 의한 것으로 $\mathrm{IL}-17 \mathrm{~A}$ 을 발현하는 $\mathrm{CD} 4^{+} \mathrm{T}$ 세포 수를 증가 시키는 방법에 의해 장염을 악화시키는 것으로 밝혀졌다.

\section{결 론}

염증성장질환에서 IL-17의 발현수준이 높아진다는 것은 마우스 의 여러 장염 모델만이 아니라, 염증성장질환을 않고 있는 환자에 서도 흔히 일어나는 현상이다. 하지만 이와 같이 IL-17의 발현 수준 이 높아지는 이유에 대해서는 마우스의 실험 시스템 및 실험 방법 에 의해 다양한 결과가 발표되고 있다. 실험 시스템에 따른 서로 각 기 다른 결과를 해석하기 위한 시도 중의 하나가, IL-17의 아형에 따 른 각기 다른 기능을 장염에 있어서 악화 또는 보호 기능이 나뉜다 는 가설이다. IL-17A와 IL-17F가 그 좋은 예이다. 하지만, IL-17A와 IL-17F가 수용체를 공유하고 있다는 문제점을 안고 있다. 뿐만 아 니라, IL-17A가 장염에서 보호 기능이 강하다는 것이 주장되고 있 지만, 특정 유전자 결핍 마우스에서 발생하는 자연발생 장염에서 는 오히려 IL-17A가 장염을 악화시키는 기능을 하는 것으로 알려 져 있다. 따라서, IL-17의 장염에서의 역할을 더 세분화된 장염 모델 을 바탕으로 밝혀져야 할 것으로 보인다(Fig. 1).

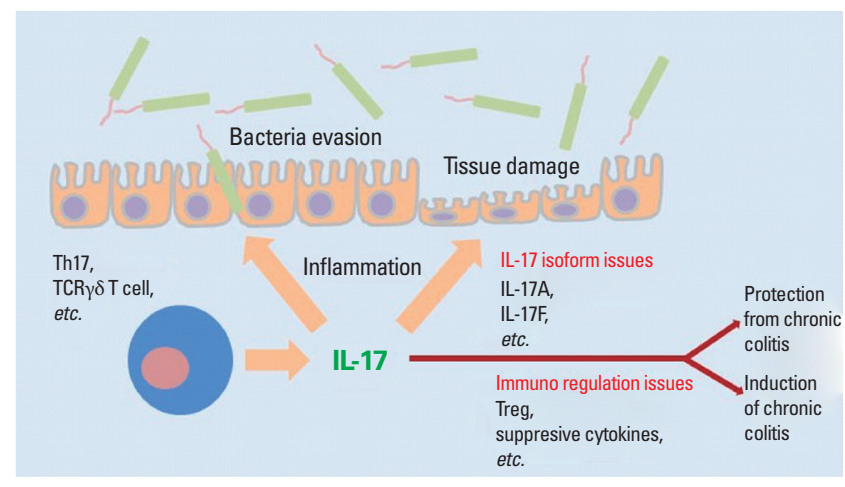

Fig. 1. IL-17 plays an important role in intestinal infection. However, the role of IL-17 has been controversial in inflammatory bowel disease (IBD). Several groups reported that IL-17 aggravates the symptoms while other groups described improvement in the symptoms. Therefore, it needs to be clarified which factors determine the role of IL-17 in IBD for improvement and worsening of inflammation.

\section{ACKNOWLEDGEMENTS}

This work was supported by a grant of the Korean Health Technology R\&D Project, Ministry of Health \& Welfare, Republic of Korea (A111838) and by the Bioimaging Research Center at GIST.

\section{REFERENCES}

1. Girlich C, Scholmerich J. Topical delivery of steroids in inflammatory bowel disease. Curr Drug Deliv 2012;9:345-9.

2. Neuman MG, Nanau RM. Inflammatory bowel disease: role of diet, microbiota, life style. Transl Res 2012;160:29-44.

3. Bernstein CN, Wajda A, Svenson LW, MacKenzie A, Koehoorn M, Jackson $\mathrm{M}$, et al. The epidemiology of inflammatory bowel disease in Canada: a population-based study. Am J Gastroenterol 2006;101:1559-68.

4. Shin DH, Sinn DH, Kim YH, Kim JY, Chang DK, Kim EJ, et al. Increasing incidence of inflammatory bowel disease among young men in Korea between 2003 and 2008. Dig Dis Sci 2011;56:1154-9.

5. Kim ES, Kim WH. Inflammatory bowel disease in Korea: epidemiological, genomic, clinical, and therapeutic characteristics. Gut Liver 2010;4:114.

6. Lee CK, Kim HJ. Pathogenesis and treatment of intestinal Behcet's disease. Korean J Gastroenterol 2007;50:3-8.

7. Monteleone I, Pallone F, Monteleone G. Th17-related cytokines: new players in the control of chronic intestinal inflammation. BMC Med 2011;9:122.

8. Morrison PJ, Ballantyne SJ, Kullberg MC. Interleukin-23 and T helper 17-type responses in intestinal inflammation: from cytokines to T-cell plasticity. Immunology 2011;133:397-408.

9. Iwakura Y, Ishigame H, Saijo S, Nakae S. Functional specialization of interleukin-17 family members. Immunity 2011;34:149-62.

10. McGeachy MJ, Cua DJ. Th17 cell differentiation: the long and winding road. Immunity 2008;28:445-53.

11. Iwakura Y, Nakae S, Saijo S, Ishigame H. The roles of IL-17A in inflammatory immune responses and host defense against pathogens. Immunol 
Rev 2008;226:57-79.

12. Cua DJ, Tato CM. Innate IL-17-producing cells: the sentinels of the immune system. Nat Rev Immunol 2010;10:479-89.

13. Gaffen SL. Structure and signalling in the IL-17 receptor family. Nat Rev Immunol 2009;9:556-67.

14. Moseley TA, Haudenschild DR, Rose L, Reddi AH. Interleukin-17 family and IL-17 receptors. Cytokine Growth Factor Rev 2003;14:155-74.

15. Hwang SY, Kim HY. Expression of IL-17 homologs and their receptors in the synovial cells of rheumatoid arthritis patients. Mol Cells 2005;19:180-4.

16. Li H, Chen J, Huang A, Stinson J, Heldens S, Foster J, et al. Cloning and characterization of IL-17B and IL-17C, two new members of the IL-17 cytokine family. Proc Natl Acad Sci U S A 2000;97:773-8.

17. Yamaguchi Y, Fujio K, Shoda H, Okamoto A, Tsuno NH, Takahashi K, et al. IL-17B and IL-17C are associated with TNF-alpha production and contribute to the exacerbation of inflammatory arthritis. J Immunol 2007;179: 7128-36.

18. Starnes T, Broxmeyer HE, Robertson MJ, Hromas R. Cutting edge: IL17D, a novel member of the IL-17 family, stimulates cytokine production and inhibits hemopoiesis. J Immunol 2002;169:642-6.

19. Kolls JK, Linden A. Interleukin- 17 family members and inflammation. Immunity 2004;21:467-76.

20. Weaver CT, Hatton RD, Mangan PR, Harrington LE. IL-17 family cytokines and the expanding diversity of effector T cell lineages. Annu Rev Immunol 2007;25:821-52.

21. Reynolds JM, Angkasekwinai P, Dong C. IL-17 family member cytokines: regulation and function in innate immunity. Cytokine Growth Factor Rev 2010;21:413-23.

22. Reynolds JM, Martinez GJ, Nallaparaju KC, Chang SH, Wang YH, Dong C. Cutting Edge: Regulation of Intestinal Inflammation and Barrier Function by IL-17C. J Immunol 2012;189:4226-30.

23. Umemura M, Yahagi A, Hamada S, Begum MD, Watanabe H, Kawaka$\mathrm{mi} \mathrm{K}$, et al. IL-17-mediated regulation of innate and acquired immune response against pulmonary Mycobacterium bovis bacille Calmette-Guerin infection. J Immunol 2007;178:3786-96.

24. Ouyang W, Kolls JK, Zheng Y. The biological functions of T helper 17 cell effector cytokines in inflammation. Immunity 2008;28:454-67.

25. Ishigame H, Kakuta S, Nagai T, Kadoki M, Nambu A, Komiyama Y, et al. Differential roles of interleukin-17A and -17F in host defense against mucoepithelial bacterial infection and allergic responses. Immunity 2009;30: 108-19.

26. Zheng Y, Valdez PA, Danilenko DM, Hu Y, Sa SM, Gong Q, et al. Interleukin-22 mediates early host defense against attaching and effacing bacterial pathogens. Nat Med 2008;14:282-9.

27. Ogawa A, Andoh A, Araki Y, Bamba T, Fujiyama Y. Neutralization of interleukin-17 aggravates dextran sulfate sodium-induced colitis in mice. Clin Immunol 2004;110:55-62.

28. Yang XO, Chang SH, Park H, Nurieva R, Shah B, Acero L, et al. Regulation of inflammatory responses by IL-17F. J Exp Med 2008;205:1063-75.

29. Kinugasa T, Sakaguchi T, Gu X, Reinecker HC. Claudins regulate the intestinal barrier in response to immune mediators. Gastroenterology 2000; 118:1001-11

30. Chen Y, Thai P, Zhao YH, Ho YS, DeSouza MM, Wu R. Stimulation of airway mucin gene expression by interleukin (IL)-17 through IL-6 paracrine/autocrine loop. J Biol Chem 2003;278:17036-43.

31. Zenewicz LA, Yancopoulos GD, Valenzuela DM, Murphy AJ, Stevens S, Flavell RA. Innate and adaptive interleukin-22 protects mice from inflammatory bowel disease. Immunity 2008;29:947-57.

32. Brand S, Beigel F, Olszak T, Zitzmann K, Eichhorst ST, Otte JM, et al. IL22 is increased in active Crohn's disease and promotes proinflammatory gene expression and intestinal epithelial cell migration. Am J Physiol Gastrointest Liver Physiol 2006;290:G827-38.

33. Sugimoto K, Ogawa A, Mizoguchi E, Shimomura Y, Andoh A, Bhan AK, et al. IL-22 ameliorates intestinal inflammation in a mouse model of ulcerative colitis. J Clin Invest 2008;118:534-44.

34. Izcue A, Hue S, Buonocore S, Arancibia-Carcamo CV, Ahern PP, Iwakura Y, et al. Interleukin-23 restrains regulatory T cell activity to drive T celldependent colitis. Immunity 2008;28:559-70.

35. Noguchi D, Wakita D, Tajima M, Ashino S, Iwakura Y, Zhang Y, et al. Blocking of IL-6 signaling pathway prevents CD4+ T cell-mediated colitis in a T(h)17-independent manner. Int Immunol 2007;19:1431-40.

36. O'Connor W Jr, Kamanaka M, Booth CJ, Town T, Nakae S, Iwakura Y, et al. A protective function for interleukin $17 \mathrm{~A}$ in $\mathrm{T}$ cell-mediated intestinal inflammation. Nat Immunol 2009;10:603-9.

37. Leppkes M, Becker C, Ivanov II, Hirth S, Wirtz S, Neufert C, et al. RORgamma-expressing Th17 cells induce murine chronic intestinal inflammation via redundant effects of IL-17A and IL-17F. Gastroenterology 2009; 136:257-67.

38. Yen D, Cheung J, Scheerens H, Poulet F, McClanahan T, McKenzie B, et al. IL-23 is essential for T cell-mediated colitis and promotes inflammation via IL-17 and IL-6. J Clin Invest 2006;116:1310-6.

39. Fina D, Sarra M, Fantini MC, Rizzo A, Caruso R, Caprioli F, et al. Regulation of gut inflammation and th17 cell response by interleukin-21. Gastroenterology 2008;134:1038-48.

40. Monteleone G, Caruso R, Fina D, Peluso I, Gioia V, Stolfi C, et al. Control of matrix metalloproteinase production in human intestinal fibroblasts by interleukin 21. Gut 2006;55:1774-80.

41. Caruso R, Fina D, Peluso I, Stolfi C, Fantini MC, Gioia V, et al. A functional role for interleukin-21 in promoting the synthesis of the T-cell chemoattractant, MIP-3alpha, by gut epithelial cells. Gastroenterology 2007; 132:166-75.

42. Fantini MC, Rizzo A, Fina D, Caruso R, Becker C, Neurath MF, et al. IL21 regulates experimental colitis by modulating the balance between Treg and Th17 cells. Eur J Immunol 2007;37:3155-63.

43. Peluso I, Fantini MC, Fina D, Caruso R, Boirivant M, MacDonald TT, et al. IL-21 counteracts the regulatory T cell-mediated suppression of human CD4+ T lymphocytes. J Immunol 2007;178:732-9.

44. Strengell M, Sareneva T, Foster D, Julkunen I, Matikainen S. IL-21 upregulates the expression of genes associated with innate immunity and Th1 response. J Immunol 2002;169:3600-5.

45. Strengell M, Matikainen S, Siren J, Lehtonen A, Foster D, Julkunen I, et al. IL-21 in synergy with IL-15 or IL-18 enhances IFN-gamma production in human NK and T cells. J Immunol 2003;170:5464-9.

46. Zhou L, Ivanov, II, Spolski R, Min R, Shenderov K, Egawa T, et al. IL-6 programs $\mathrm{T}(\mathrm{H})-17$ cell differentiation by promoting sequential engagement of the IL-21 and IL-23 pathways. Nat Immunol 2007;8:967-74.

47. Korn T, Bettelli E, Gao W, Awasthi A, Jager A, Strom TB, et al. IL-21 initiates an alternative pathway to induce proinflammatory $\mathrm{T}(\mathrm{H}) 17$ cells. Nature 2007;448:484-7.

48. Nurieva R, Yang XO, Martinez G, Zhang Y, Panopoulos AD, Ma L, et al. Essential autocrine regulation by IL-21 in the generation of inflammatory T cells. Nature 2007;448:480-3.

49. Park SG, Mathur R, Long M, Hosh N, Hao L, Hayden MS, et al. T regulatory cells maintain intestinal homeostasis by suppressing gammadelta $\mathrm{T}$ cells. Immunity 2010;33:791-803.

50. Do JS, Visperas A, Dong C, Baldwin WM 3rd, Min B. Cutting edge: Generation of colitogenic Th17 CD4 T cells is enhanced by IL-17+ gammadelta T cells. J Immunol 2011;186:4546-50. 